\title{
Editorial: ASEAN and Taiwan Relations
}

Finally, the second edition of Journal of ASEAN Studies is published this December.

In this second edition, JAS covers fifth scholarly articles. First article entitled "Relationship between Military Expenditure and Economic Growth in ASEAN: Evidence from Indonesia", written by Tangguh Chairil, Dedy S. Sinaga, and Annisa I Febrianti from Indonesia Defense University. In this article, writers investigate the relations between military expenditure and economic growth in Southeast Asia. They examine the relations by first reviewing literature on the relationship between military expenditure and economic growth, then by empirically testing the causal relationship between the two variables by using the Augmented Sollow Growth Model in the case of Indonesia. The result shows that Indonesia's military expenditure has positive effect on the country's economic growth, which is most possibly caused by development of human capital as effect of military expenditure.

While Chairil, Sinaga, and Febrianti's article focuses on the relations between military and economic growth, the second article focuses on the relations between ASEAN members with their non-ASEAN neighbour. The second article entitled "India's Democratic Identity and Its Policy towards Myanmar from 1988 to 2010" written by Htwe Hteik Tin Lwin from Myanmar Ministry of Foreign Affairs focuses on the relations between Myanmar and India. She argues that in the background of Indo-Myanmar development cooperation, India has made efforts to promote democratic value in Myanmar differently from other western democratic countries. Engagement policy has shaped Indo-Myanmar relations in the 1990s. India 'engagement policy', 'non-isolation' and 'development cooperation' with Myanmar government has brought up contractions.

The third, fourth, and the fifth articles still discuss the relations between ASEAN countries with its East Asia neighbor with particular emphasis on the relations between Indonesia and Taiwan. Luh Nyoman Ratih Wagiswari Kabinawa from Bina Nusantara University, writes about Economic and Socio-Cultural Relations between Indonesia and Taiwan: An Indonesian Perspective, 1990-2012. Her article analyzes the puzzle why did Indonesia maintain durable economic and socio-cultural relations with Taiwan? She argues that due to the Indonesian people as promoter of ideas lead interactions with Taiwan, Indonesia is able to maintain its durable economic and socio-cultural relations with Taiwan despite under the absence of diplomatic relations. People-to-people interaction builds three kinds of interactions between Indonesia and Taiwan on the issue of economic and socio-cultural: unofficial interaction, semi-official interaction, and official interaction.

While the third article focuses on both economic and socio-cultural aspect, the fourth article entitled Forging ASEAN and East Asia Cooperation: The importance of counterparts in promoting people-topeople interaction between Indonesia and Taiwan, Paramitaningrum from Tamkang University, Taiwan examines how students can actually become one of the significant actors to bridge Indonesia Taiwan relations despite the lack of diplomatic relations between both countries.

The fifth article explores the condition of migrant workers from ASEAN countries in Taiwan. In their article entitled ASEAN Migrants: A Boon for Taiwan's Aging Populace, Hong-Ming Huang and JennJaw Soong asked whether the Taiwanese government policy that allows for Southeast Asian migrants to care for the elderly in Taiwan a good one, or a bad one? In order to answer the question, they analyze the political- 
economic aspects of this policy and offer certain recommendations and conclusions. One conclusion is the fact that Southeast Asian workers take better care of the elderly in Taiwan when eldercare is provided through institutions, rather than if the care was provided by just one foreign caregiver engaged directly by families of the elderly. The positive effects of 'institution-style' workers are reflected in the work performance, life quality and management as well as labor rights protection.

Last but not least, editor-in-chief would like to express highest appreciation for authors who submitted their articles as response from our invitation. We also thank to Indonesian Association for International Relations for supporting this joint publication with Centre for Business and Diplomatic Studies (CBDS) Department of International Relations Bina Nusantara University. In order to become internationally renowned journal, we are very happy to receive comments, feedback and advice for quality improvement of the journal. We hope JAS will bring an academic oasis that nurture new thoughts and encourage innovative practical application of ASEAN studies in Southeast Asian region and the world.

Jakarta, 1 December 2013

Tirta Nugraha Mursitama, PhD

Editor-in-chief 